\title{
Complimentary address from the President of the Korean Society of Plant Pathology
}

\author{
Young Ryun Chung ${ }^{1}$
}

Published online: 9 October 2015

(C) The Phytopathological Society of Japan and Springer Japan 2015

On behalf of all the members of the Korean Society of Plant Pathology (KSPP), I extend to you congratulations on the Centennial Anniversary of Phytopathological Society of Japan (PSJ). As one of the oldest and largest phytopathological societies, next to the American Phytopathological Society, in the world, PSJ contributed immensely to the chrysalis of plant pathology and its education areas. The close proximity of Japan to Korea in the eastern Asia is putting the two countries in the same boat as they are both faced by the daunting task of efficient agricultural production amidst the climate change. I am more than convinced that the remarkable work of PSJ members did more than help solve the problems of not only Japan and Korea but also other countries. For example, an outbreak of rice stripe disease has occurred recently in Japan, Korea and China by favorable hot weather conditions and insecticide resistance of the vectors, rice planthoppers which migrate from China to other neighboring countries to spread rice stripe virus. Pesticide resistance is also imminent problem we have to solve together by exchanging our knowledge as the pesticides are commonly

This article is an abstract of the complimentary address given at the 100th Anniversary Ceremony of the Phytopathological Society of Japan, which was held on Saturday, March 28, 2015, at Academy Hall, Academy Common Building of Meiji University, Tokyo, Japan.

Young Ryun Chung is President of the Korean Society of Plant Pathology.

Young Ryun Chung

yrchung@gnu.ac.kr

1 Division of Applied Life Science (BK21 Plus), Plant Molecular Biology and Biotechnology Research Center, Gyeongsang National University, Jinju 660-701, Korea used and the resistance develops easily in the community of various plant pathogens. The prodigious advances in plant pathology all over the world would not have been possible without the phenomenal Japanese plant pathologists who are acclaimed for their unwonted work on basic findings and applied biotechnology. As close neighbors and ineluctable partners, I believe, it is necessary for plant pathologists in both Japanese and Korean phytopathological societies should collaborate for the smarter control of the epidemics of this disease. We can never predict the disaster by plant pests although we live in very scientifically developed smart phone period. PSJ and KSPP already collaborated through three joint symposiums held every 2 years since 2010; their unyielding passion for plant pathology will only strengthen the vigorous and conducive academic exchange through the joint symposiums in the future. In 2017, KSPP will host the fourth Asian Plant Pathology meeting at Jeju island and hope many members of PSJ will join. Congratulations again from all the members of the KSPP for the marvelous journey of 100 years and we hope the same for the future also. 